Correspondence

Derek R. Lovley

dlovley@microbio.umass.edu

Received 2 February 2007

Revised 11 June 2007

Accepted 20 June 2007

\section{Involvement of Geobacter sulfurreducens SfrAB in acetate metabolism rather than intracellular, respiration-linked $\mathrm{Fe}$ (III) citrate reduction}

\author{
Maddalena V. Coppi, ${ }^{1}$ Regina A. O'Neil, ${ }^{1}$ Ching Leang, ${ }^{1}$ Franz Kaufmann, ${ }^{2}$ \\ Barbara A. Methé, ${ }^{3}$ Kelly P. Nevin, ${ }^{1}$ Trevor L. Woodard, ${ }^{1}$ Anna Liu ${ }^{4}$ \\ and Derek R. Lovley ${ }^{1}$ \\ ${ }^{1}$ Department of Microbiology, 203N Morrill Science Center IVN, University of Massachusetts at \\ Amherst, Amherst, MA 01003, USA \\ ${ }^{2}$ Ciba Specialty Chemicals Ltd, Klybeckstr. 141, CH-4002 Basel, Switzerland \\ ${ }^{3}$ The Institute for Genomic Research, 9712 Medical Center Dr., Rockville, MD 20850, USA \\ ${ }^{4}$ Department of Mathematics and Statistics, Lederle Graduate Research Tower, Box 34515, \\ University of Massachusetts at Amherst, Amherst, MA 01003, USA
}

A soluble ferric reductase, SfrAB, which catalysed the NADPH-dependent reduction of chelated $\mathrm{Fe}(\mathrm{III})$, was previously purified from the dissimilatory Fe(III)-reducing micro-organism Geobacter sulfurreducens, suggesting that reduction of chelated forms of Fe(III) might be cytoplasmic. However, metabolically active spheroplast suspensions could not catalyse acetate-dependent Fe(III) citrate reduction, indicating that periplasmic and/or outer-membrane components were required for $\mathrm{Fe}(\mathrm{III})$ citrate reduction. Furthermore, phenotypic analysis of an SfrAB knockout mutant suggested that SfrAB was involved in acetate metabolism rather than respiration-linked Fe(III) reduction. The mutant could not grow via the reduction of either Fe(III) citrate or fumarate when acetate was the electron donor but could grow with either acceptor if either hydrogen or formate served as the electron donor. Following prolonged incubation in acetate : fumarate medium in the absence of hydrogen and formate, an 'acetate-adapted' SfrAB-null strain was isolated that was capable of growth on acetate : fumarate medium but not acetate : Fe(III) citrate medium. Comparison of gene expression in this strain with that of the wild-type revealed upregulation of a potential NADPH-dependent ferredoxin oxidoreductase as well as genes involved in energy generation and amino acid uptake, suggesting that NADPH homeostasis and the tricarboxylic acid (TCA) cycle were perturbed in the 'acetate-adapted' SfrAB-null strain. Membrane and soluble fractions prepared from the 'acetate-adapted' strain were depleted of NADPH-dependent Fe(III), viologen and quinone reductase activities. These results indicate that cytoplasmic, respiration-linked reduction of $\mathrm{Fe}(\mathrm{III})$ by $\mathrm{Sfr} A \mathrm{~B}$ in vivo is unlikely and suggest that deleting SfrAB may interfere with growth via acetate oxidation by interfering with NADP regeneration.

\footnotetext{
Abbreviations: AQDS, anthraquinone 2,6-disulfonate; FNOR, ferredoxin oxidoreductase; ORT-PCR, quantitative RT-PCR. The Array Express (www.ebi.ac.uk/arrayexpress/) accession number for the microarray data for this paper is E-TIGR-130.

Three supplementary figures, and supplementary tables of the primers used in QRT-PCR and genes that are up- or downregulated in the acetate-adapted SfrAB-null strain during growth in chemostats in acetate:fumarate medium are available with the online version of this paper, together with an overview and additional discussion of the microarray analysis.
}

\section{INTRODUCTION}

Geobacter species are dissimilatory $\mathrm{Fe}(\mathrm{III})$-reducing Deltaproteobacteria that have evolved the ability to transfer electrons across the outer membrane and onto a variety of electron acceptors that are too large to enter the cell, including insoluble $\mathrm{Fe}(\mathrm{III})$ and $\mathrm{Mn}$ (IV) oxides (Lovley et al., 2004; Reguera et al., 2005), the quinone groups of humic acids (Lovley et al., 1996; Scott et al., 1998), and the anodes of microbial fuel cells (reviewed by Lovley, 2006). In addition, Geobacter species can reduce soluble electron 
acceptors that have the potential to enter the periplasm and/or cytoplasm. These include fumarate, low-molecularmass electron-shuttling compounds such as anthraquinone 2,6-disulfonate (AQDS), the radionuclides $\mathrm{U}(\mathrm{VI})$ and $\mathrm{Tc}(\mathrm{VII})$, and a variety of chelated forms of $\mathrm{Fe}(\mathrm{III})$ (Lovley et al., 2004).

Valuable insights into the electron transport pathways to $\mathrm{Fe}(\mathrm{III})$ have been gained through the study of two Geobacter species, Geobacter metallireducens (Lovley et al., 1993) and Geobacter sulfurreducens (Caccavo et al., 1994), for which a complete genome sequence and a genetic system are available (Coppi et al., 2001; Methé et al., 2003). Due to technical considerations, chelated forms of Fe(III), most often $\mathrm{Fe}(\mathrm{III})$ citrate and $\mathrm{Fe}(\mathrm{III})$ chelated with nitrilotriacetic acid (Fe(III)-NTA), are frequently used for laboratory studies addressing $\mathrm{Fe}(\mathrm{III})$ reduction by Geobacter species (Butler et al., 2004; Ding et al., 2006; Esteve-Núñez et al., 2005; Kim et al., 2005, 2006; Leang et al., 2003; Lloyd et al., 2003; Methé et al., 2005; Núñez et al., 2004, 2006). An understanding of the similarities and differences between the electron transport pathways to $\mathrm{Fe}(\mathrm{III})$ citrate and insoluble $\mathrm{Fe}(\mathrm{III})$ oxides is, therefore, crucial for determining the environmental relevance of these studies.

The reduction of $\mathrm{Fe}(\mathrm{III})$ oxides clearly occurs at the cell surface (Lovley et al., 2004; Nevin \& Lovley, 2000) and involves a variety of outer-membrane components, including cytochromes (Mehta et al., 2005), a putative multicopper protein (Mehta et al., 2006) and pili, which are postulated to act as electrically conductive nanowires extending the $\mathrm{Fe}$ (III)-oxide reducing capacity of Geobacter species beyond the cell surface (Reguera et al., 2005). In contrast, the subcellular localization of the reduction of chelated forms of $\mathrm{Fe}(\mathrm{III})$ is not known. Genetic studies conducted in G. sulfurreducens have implicated several periplasmic and outer-membrane cytochromes in $\mathrm{Fe}(\mathrm{III})$ citrate reduction (Butler et al., 2004; Kim et al., 2005, 2006; Leang et al., 2003; Lloyd et al., 2003), suggesting that the reduction of $\mathrm{Fe}(\mathrm{III})$ citrate might occur at the cell surface. Biochemical studies performed in G. sulfurreducens have provided conflicting information regarding the site of $\mathrm{Fe}(\mathrm{III})$ chelate reduction. Purification of SfrAB, a twosubunit complex capable of catalysing the NADPHdependent reduction of $\mathrm{Fe}(\mathrm{III})$-NTA, from the soluble fraction (Kaufmann \& Lovley, 2001) suggested that $\mathrm{Fe}(\mathrm{III})$ chelates might be reduced within the cytoplasm. Membrane-bound, multi-subunit complexes with the capacity to catalyse NADH-dependent Fe(III)-NTA reduction (Gaspard et al., 1998; Magnuson et al., 2000) have also been isolated, one of which was reported to be associated the outer-membrane fraction (Gaspard et al., 1998).

Both the subcellular localization of Fe(III) citrate reduction and the physiological role of SfrAB were addressed in this study. The results of this work are consistent with $\mathrm{Fe}(\mathrm{III})$ citrate reduction occurring outside the cytoplasm, and suggest that SfrAB is involved in acetate metabolism and does not participate directly in the reduction of $\mathrm{Fe}(\mathrm{III})$ chelates, as was previously proposed (Kaufmann \& Lovley, 2001).

\section{METHODS}

Bacterial strains and culture conditions. Escherichia coli strain DH5 $\alpha$ [supE44 $\phi 80$ lacZAM15 $\Delta$ (lacZYA-argF)U169 deoR recA1 endA1 hsdR17 phoA supE44 thi-11 gyrA96 relA1 $\lambda^{-}$] (Woodcock et al., 1989) was used for routine DNA manipulations. G. sulfurreducens strain DL1, a wild-type derivative of ATCC 51573 (Caccavo et al., 1994; Coppi et al., 2001), was obtained from our laboratory culture collection. During growth of $G$. sulfurreducens strains in batch cultures, cells were cultivated anaerobically at $30{ }^{\circ} \mathrm{C}$ under an $\mathrm{N}_{2}: \mathrm{CO}_{2}(80: 20)$ atmosphere in two defined liquid freshwater media, $\mathrm{NBF}$ and FWFC, which contained $40 \mathrm{mM}$ fumarate or $55 \mathrm{mM} \mathrm{Fe}$ (III) citrate, respectively, as the electron acceptor (Lovley \& Phillips, 1988; Coppi et al., 2001, 2004). Acetate (1-15 mM), formate (40 mM), cysteine $(1 \mathrm{mM})$, and antibiotics $\left(200 \mu \mathrm{g}\right.$ kanamycin $\mathrm{ml}^{-1}$ and/or $400 \mu \mathrm{g}$ streptomycin $\mathrm{ml}^{-1}$ ) were added from concentrated stock solutions as needed. Unless otherwise indicated, cysteine was routinely added to all fumarate media as a reductant.

Culture in the presence of hydrogen was accomplished by injecting $10 \mathrm{ml}$ hydrogen gas into the headspace of $27 \mathrm{ml}$ pressure tubes containing $10 \mathrm{ml}$ medium, resulting in a headspace composition of $37 \% \mathrm{H}_{2}, 12.6 \% \mathrm{CO}_{2}, 50.4 \% \mathrm{~N}_{2}$ at a total pressure of $\sim 1.61 \times 10^{5} \mathrm{~Pa}$. Hydrogen-containing tubes were incubated horizontally at $30{ }^{\circ} \mathrm{C}$ with constant shaking at 100 r.p.m.

Continuous culture of wild-type and mutant strains was performed as previously described (Esteve-Núñez et al., 2005). Briefly, cells were cultured under an $\mathrm{N}_{2}: \mathrm{CO}_{2}(80: 20)$ atmosphere at $30{ }^{\circ} \mathrm{C}$ and a dilution rate of $0.05 \mathrm{~h}^{-1}$ in a working volume of $200 \mathrm{ml}$ antibioticand reductant-free freshwater medium (Lovley \& Phillips, 1988) containing $27.5 \mathrm{mM}$ fumarate as the electron acceptor and a limiting concentration of acetate $(5 \mathrm{mM})$ as electron donor and carbon source.

Preparation of whole-cell and spheroplast suspensions. All buffers were prepared using strict anaerobic techniques and all manipulations were carried out at $30{ }^{\circ} \mathrm{C}$ in an anaerobic chamber containing an atmosphere of $7 \% \mathrm{H}_{2}$ and $10 \% \mathrm{CO}_{2}$ balanced with $\mathrm{N}_{2}$. Intact-cell and spheroplast suspensions were prepared in parallel from two $500 \mathrm{ml}$ aliquots derived from a single, mid-exponential, acetate:fumarate $(15 \mathrm{mM}: 40 \mathrm{mM})$ culture. Intact-cell suspensions were prepared as previously described (Coppi et al., 2004; Leang et al., 2003). Because previously published methods for the production of $G$. sulfurreducens spheroplasts (Galushko \& Schink, 2000; Kaufmann \& Lovley, 2001) failed to yield homogeneous spheroplast preparations reproducibly, the spheroplast preparation protocol of Witholt et al. (1976) was adapted for use in G. sulfurreducens. Intact cells were harvested by centrifugation for $15 \mathrm{~min}$ at $6000 \mathrm{~g}$ and resuspended in $\sim 100 \mathrm{ml}$ spheroplast wash medium, consisting of $\left(\mathrm{g} \mathrm{l}^{-1}\right): 0.42$ $\mathrm{KH}_{2} \mathrm{PO}_{4}, 0.22 \mathrm{~K}_{2} \mathrm{HPO}_{4}, 0.38 \mathrm{KCl}, 4.96 \mathrm{NaCl}, 1.8 \mathrm{NaHCO}_{3}$ and 0.5 $\mathrm{Na}_{2} \mathrm{CO}_{3}$. The washed cells were then pelleted by centrifugation at $6000 \mathrm{~g}$ for $6 \mathrm{~min}$ and resuspended in $30 \mathrm{ml}$ spheroplast wash medium containing $350 \mathrm{mM}$ sucrose. Following another $6 \mathrm{~min}$ centrifugation at $6000 \mathrm{~g}$, the cells were resuspended in $10 \mathrm{ml} 250 \mathrm{mM} \mathrm{Tris} / \mathrm{HCl}$ $(\mathrm{pH} 7.5)$, and this was designated time zero. After $1 \mathrm{~min}$ of incubation at $30{ }^{\circ} \mathrm{C}, 1 \mathrm{ml} 500 \mathrm{mM}$ EDTA (pH 8.0) was added, followed by the addition of $10 \mathrm{ml} 700 \mathrm{mM}$ sucrose at $2 \mathrm{~min}, 150 \mathrm{mg}$ lysozyme at $3.5 \mathrm{~min}$, and $20 \mathrm{ml}$ water at $4 \mathrm{~min}$ to induce osmotic shock. Immediately following the osmotic shock, spheroplasts were harvested by centrifugation at $20000 \mathrm{~g}$ for $10 \mathrm{~min}$. The supernatant (periplasmic fraction) was reserved for further analysis, and the 
spheroplasts were resuspended in $5 \mathrm{ml}$ spheroplast wash medium containing $350 \mathrm{mM}$ sucrose.

Acridine orange staining and epifluorescence microscopy of wholecell and spheroplast preparations as well as transmission electron microscopy of spheroplast thin sections were performed as previously described (Afkar et al., 2005; Lovley \& Phillips, 1988). A cytoplasmic fraction was prepared by subjecting spheroplast suspensions to two passes through a French pressure cell at $40000 \mathrm{kPa}$ followed by lowspeed centrifugation at $20000 \mathrm{~g}$ for $5 \mathrm{~min}$ at $4{ }^{\circ} \mathrm{C}$ to remove intact spheroplasts and debris, and high-speed centrifugation at $100000 \mathrm{~g}$ for $45 \mathrm{~min}$ at $4{ }^{\circ} \mathrm{C}$ to remove membranes.

Resting intact-cell and spheroplast suspension assays. Cell suspension assays were carried out in an isotonic buffer (basal wash medium; Leang et al., 2003) as previously described (Coppi et al., 2004). Spheroplast suspension assays were performed identically except for the substitution of the basal wash medium with spheroplast wash buffer containing $350 \mathrm{mM}$ sucrose (see above). Suspensions were provided with $20 \mathrm{mM} \mathrm{Fe}$ (III) citrate, $10 \mathrm{mM}$ fumarate or $1 \mathrm{mM}$ AQDS as the electron acceptor and were incubated in either the absence or presence of $20 \mathrm{mM}$ acetate.

DNA extraction and manipulation. G. sulfurreducens genomic DNA was extracted using the MasterPure complete DNA \& RNA Purification kit (Epicentre Technologies) or the Genome DNA kit (Bio 101). Taq DNA polymerase (Qiagen) was used for all PCR amplifications. Plasmid purification, PCR product purification and gel extractions were performed with the following kits: the QIAprep Spin Miniprep kit, the Qiagen Plasmid Midi kit, the QIAquick PCR Purification kit, and the QIAquick Gel Extraction kit (Qiagen). Ligations, transformations into E. coli, Southern blotting and other routine DNA manipulations were carried out according to the methods outlined in Sambrook et al. (1989). Restriction enzymes and T4 DNA ligase were purchased from New England Biolabs. Radiolabelled probes for Southern analysis were labelled with the NEBlot kit (New England Biolabs) and $\left[\alpha_{-}{ }^{32} \mathrm{P}\right] \mathrm{dCTP}$ (Perkin Elmer) according to the manufacturer's instructions.

Construction of an SfrAB-null ( $\triangle$ sfrAB::kan) strain. $S f r A B$ is encoded by a two-gene cluster ( $s f r B A)$, consisting of the $s f r B$ gene followed by a 126 bp intergenic region and the $s f r A$ gene (Kaufmann \& Lovley, 2001; Methé et al., 2003). In order to disrupt the $s f r B A$ cluster by homologous recombination, a linear DNA fragment, consisting of a kanamycin resistance cassette flanked by the first $0.58 \mathrm{~kb}$ of the $s f r B$ gene and the last $0.54 \mathrm{~kb}$ of the $s f r A$ gene, was constructed. Insertion of this fragment into the chromosome via a double recombination event would result in replacement of $78 \%$ of the $s f r B A$ cluster (the final $72 \%$ of the $s f r B$ gene, the intergenic region, and the initial $80 \%$ of the $s f r A$ gene) with the kanamycin resistance cassette.

The $0.58 \mathrm{~kb} s f r B$ and $0.54 \mathrm{~kb} s f r A$ fragments were amplified from $G$. sulfurreducens genomic DNA with primer combinations FR01 and FR02 (5'-GCGAAGGTCTGAACGGAGG-3' and 5'-CGCGGATGATATCAAGCG-3') and FR03 and FR04 (5'-GAGTCGCTTGATATCATCCGCAACGCCCGTGAGGACTGGG-3' and 5'-CGATTGTTCG CCCGGAATCAAGC-3'), respectively (EcoRV sites indicated in bold). Using the amplification conditions described by Lloyd et al. (2003) and an annealing temperature of $50{ }^{\circ} \mathrm{C}$, the two fragments were fused by recombinant PCR and the resultant $1.12 \mathrm{~kb}$ fusion product was amplified with distal primers, FR01 and FR04. The fusion product was subsequently inserted into the pGem-T Easy vector (Promega) according to the manufacturer's instructions, and the resultant plasmid was cleaved with $E c o R V$, which cut at the junction of the $s f r B$ and $s f r A$ fragments. A kanamycin resistance cassette was amplified from pBBR1-MCS2 (Kovach et al., 1994) with primers KanEcoRV and KanR (5'-CCCGATATCGGATGAATGTCAGC-3' and 5'-CCCGATATCGCGGTGGAATCG-3', EcoRV sites indicated in bold), treated with EcoRV and inserted at the EcoRV site at the junction of the $s f r B$ and $s f r A$ fragments. A plasmid containing the kanamycin resistance cassette in the same orientation as the fragments of the $s f r B$ and $s f r A$ coding regions was identified and designated pTFr. The final $2.3 \mathrm{~kb}$ linear fragment used for disruption of the $s f r B A$ cluster was excised from pTFr with EcoRI.

Electroporation and mutant isolation were performed as previously described (Coppi et al., 2001; Lloyd et al., 2003). Kanamycin-resistant colonies were recovered on NBAF-YE plates (Coppi et al., 2001) supplemented with $200 \mu \mathrm{g}$ kanamycin $\mathrm{ml}^{-1}$, purified by streaking, and inoculated into pressure tubes containing $10 \mathrm{ml}$ kanamycincontaining acetate: fumarate medium and $10 \mathrm{ml}$ hydrogen gas in the headspace. The genotype of these kanamycin-resistant strains was determined by Southern blotting and by screening with PCR primers FR01 and FR04, which yield differently sized amplicons, 2.3 and $4.7 \mathrm{~kb}$, respectively, for the SfrAB-null and wild-type strains. During Southern blot analysis, genomic DNA from wild-type G. sulfurreducens and various kanamycin-resistant isolates was digested with $B g l \mathrm{II}$, and blots were probed with the $2.3 \mathrm{~kb}$ fragment of pTFr used for homologous recombination. The presence and placement of the $\triangle s f r A B:$ : kan mutation was confirmed by detection of two fragments $(1.2 \mathrm{~kb}$ and $1.9 \mathrm{~kb})$ in kanamycin-resistant isolates versus a single radiolabelled fragment $(5.5 \mathrm{~kb})$ in genomic DNA from the wild-type strain (data not shown). One of the mutants was selected as the representative SfrAB-null strain.

Because a large segment of the sfrBA cluster had been replaced with the kanamycin resistance cassette in the SfrAB-null strain, reversion to wild-type by excision of the antibiotic cassette was not possible, rendering further selection with antibiotics unnecessary. The SfrABnull strain was subsequently cultured in the absence of antibiotics and screened routinely for wild-type contamination with primers FR01 and FR04 (described above) as well as primers FR01 and FRWT (5'GCACCATGATGTTGACCGAG-3'), which amplify sequences from the wild-type but not the SfrAB-null strain.

Construction of an SfrAB expression vector and complementation of the acetate-adapted SfrAB-null strain. A plasmid from a G. sulfurreducens genomic DNA library containing the sfrBA cluster was obtained from Barbara Methé at the Institute for Genomic Research (Rockville, MD, USA). The sfrBA cluster was excised from this plasmid with the restriction enzymes BsiWI and BstBI, treated with Klenow fragment and inserted into the SmaI site of pCDS (Coppi et al., 2001) to generate the expression vector pCDSsfrAB. The acetate-adapted SfrAB-null strain was made electrocompetent and transformed with pCDSsfrAB as previously described (Coppi et al., 2001). Streptomycin-resistant colonies were recovered on NBAF-YE plates supplemented with $400 \mu \mathrm{g}$ streptomycin $\mathrm{ml}^{-1}$. The resulting streptomycin-resistant colonies were inoculated into liquid medium containing $400 \mu \mathrm{g}$ streptomycin $\mathrm{ml}^{-1}$ and screened for the presence of the plasmid by PCR amplification of a vector-specific fragment with the universal M13-reverse primer and primer FRWT and by isolating plasmid DNA and digesting it with EcoRI. Amplification conditions were $3 \mathrm{~min}$ at $94{ }^{\circ} \mathrm{C}$ followed by 30 cycles of $30 \mathrm{~s}$ at $94{ }^{\circ} \mathrm{C}$, $1 \mathrm{~min}$ at $55^{\circ} \mathrm{C}$ and $1 \mathrm{~min}$ at $72{ }^{\circ} \mathrm{C}$, and a final $10 \mathrm{~min}$ extension at $72{ }^{\circ} \mathrm{C}$. One plasmid-containing, SfrAB-null strain was selected for further study; this strain was cultured in medium supplemented with streptomycin at all times.

Enzymic assays. Membrane and soluble fractions for enzymic assays were prepared from batch or chemostat cultures under anaerobic conditions as described by Kaufmann \& Lovley (2001) except that intact cells were washed in $50 \mathrm{mM}$ HEPES ( $\mathrm{pH} 7.0), 1 \mathrm{mM} \mathrm{MgSO}_{4}$ and resuspended in $50 \mathrm{mM}$ Tris/ $\mathrm{HCl}(\mathrm{pH} 7.5), 1 \mathrm{mM} \mathrm{MgSO}$ prior to lysis in the French pressure cell. All enzymic assays were carried out 
at $30{ }^{\circ} \mathrm{C}$ using strict anaerobic techniques, except for measurement of malate dehydrogenase activity, which was performed aerobically. Malate dehydrogenase activity was determined by monitoring the oxidation of NADH at $340 \mathrm{~nm}\left(\varepsilon=6.22 \mathrm{mM}^{-1} \mathrm{~cm}^{-1}\right)$ in the presence of oxaloacetate (Reeves et al., 1971). Pyruvate-ferredoxin oxidoreductase and 2-oxoglutarate-ferredoxin oxidoreductase activity were determined by monitoring pyruvate- or oxoglutarate-dependent reduction of benzyl viologen at $578 \mathrm{nM}\left(\varepsilon=8.6 \mathrm{mM}^{-1} \mathrm{~cm}^{-1}\right)$ in a modified form of the assay buffer used by Brandis-Heep et al. (1983), which consisted of $100 \mathrm{mM}$ Tricine $/ \mathrm{NaOH}$ ( $\mathrm{pH} 8.5$ ), $0.05 \mathrm{mM}$ coenzyme A, $0.1 \mathrm{mM}$ thiamine pyrophosphate, $5 \mathrm{mM} \mathrm{MgCl}_{2}, 5 \mathrm{mM}$ $\beta$-mercaptoethanol, $1 \mathrm{mM}$ benzyl viologen and either $10 \mathrm{mM} \mathrm{2-}$ oxoglutarate or $10 \mathrm{mM}$ pyruvate. NADPH-dependent reduction of $\mathrm{Fe}$ (III)-NTA was determined by monitoring the formation of an $\mathrm{Fe}$ (II)ferrozine complex at $562 \mathrm{~nm}\left(\varepsilon=28 \mathrm{mM}^{-1} \mathrm{~cm}^{-1}\right)$ as previously described (Kaufmann \& Lovley, 2001). NADPH-dependent reduction of benzyl viologen and AQDS reduction were determined in a reaction buffer containing Tris/HCl ( $\mathrm{pH} 7.5), 0.2 \mathrm{mM} \mathrm{NADPH}$ and either $1 \mathrm{mM}$ benzyl viologen or AQDS by monitoring the reduction of benzyl viologen at $578 \mathrm{~nm}\left(\varepsilon=8.6 \mathrm{mM}^{-1} \mathrm{~cm}^{-1}\right)$ or that of AQDS at $436 \mathrm{~nm}$ $\left(\varepsilon=3.5 \mathrm{mM}^{-1} \mathrm{~cm}^{-1}\right)$.

Microarray analysis of global gene expression. A description of the microarray experiment and relevant data in MIAME format have been deposited in the Array Express repository (www.ebi.ac.uk/ arrayexpress/; accession number E-TIGR-130). The methods used for cell harvesting, RNA preparation, microarray design and microarray hybridization have been previously described (DiDonato et al. 2006; Methé et al., 2005; Núñez et al., 2006). Briefly, total mRNA was isolated from three pairs of identically treated steady-state chemostat cultures of the wild-type and acetate-adapted SfrAB-null strains (biological replicates). cDNA was prepared from $5 \mu \mathrm{g}$ total RNA from each member of a biological replicate and labelled with either cyanine 3 or cyanine 5 , then mixed and hybridized to the microarray. A total of 22 replicate hybridizations were carried out, six for the first biological replicate and eight for each of the remaining two.

Signal intensities from the replicate hybridizations could not be treated as independent values, because the variation among signal intensities for replicate hybridizations performed on RNA extracted from the individual biological replicates was significantly smaller than the variation among all of the replicate hybridizations. Differentially expressed genes were, therefore, identified by combining two independent statistical approaches. In the first, signal intensities from the replicate hybridizations for each of the three biological replicates were analysed separately using significance analysis of microarrays (SAM; Tusher et al., 2001) as previously described (Methé et al., 2005). Only the genes (147) that were identified by SAM in at least two out of three biological replicates were considered to be differentially expressed. Differentially expressed genes were also identified by linear models with B statistics by applying the LIMMA statistical software package (Smyth, 2005; http://bioinf.wehi.edu.au/limma/). Specifically, for each gene, a linear model with fixed biological replicate effects was used to estimate the average log gene expression ratio of all replicates. The moderated $t$-statistics for the estimate (standard error moderated based on the empirical Bayes shrinkage), the log-odd of differential expression (the $B$ statistic), and the false-discovery-rate-adjusted $P$ value were then computed. A total of 165 differentially expressed genes with adjusted $P$-values $<1 \times 10^{-7}$ and $B$-values greater than 10.0 were identified using this procedure. There was considerable overlap (90\%) between the results of the two statistical analyses.

Quantitative reverse transcriptase PCR (QRT-PCR). Cells from three steady-state, wild-type or $s f r A B$ : kan acetate: fumarate chemostats were harvested by centrifugation and pooled for RNA extraction. Total RNA was extracted with the RNeasy kit (Qiagen Inc) and any residual DNA was removed via an on-column RNase treatment, performed according to the manufacturer's instructions. cDNA was synthesized with the Superscript I RNaseH reverse transcriptase and random primers (Invitrogen) and QRT-PCR was performed with the SYBR Green PCR Master kit (Applied Biosytems). Relative expression levels were calculated by the $2^{-\Delta \Delta \mathrm{CT}}$ method (Livak \& Schmittgen, 2001). Gene-specific primers utilized for QRT-PCR are listed in Supplementary Table S1, available with the online version of this paper.

Analytical techniques. Protein concentrations were determined by the bicinchoninic acid method with BSA as a standard (Smith et al., 1985). Cell densities were determined by acridine orange staining and epifluorescence microscopy (Lovley \& Phillips, 1988). Fe(II) concentrations were determined with the ferrozine assay (Lovley \& Phillips, 1988). Turbidity was monitored by placing pressure tubes (path length $1.5 \mathrm{~cm}$ ) directly into a Genesys 2 spectrophotometer (Spectronics Instruments). Organic acids produced during spheroplast and cell suspension studies were separated, with a Fast Acid Analysis column (Bio-Rad) and a mobile phase of $5 \mathrm{mM}$ sulfuric acid on an HP series 1100 high pressure liquid chromatograph equipped with a UV detector, and quantified at $215 \mathrm{~nm}$.

\section{RESULTS AND DISCUSSION}

\section{Fe(III) reduction by spheroplasts}

Suspensions of G. sulfurreducens spheroplasts were prepared in order to investigate the subcellular localization of $\mathrm{Fe}$ (III) citrate reduction. The homogeneity and integrity of these suspensions was confirmed by phase-contrast and transmission electron microscopy (Fig. 1a) as well as by comparison of the amount of malate dehydrogenase activity present in a lysed spheroplast suspension $\left(7.44 \mu \mathrm{mol} \mathrm{mg}^{-1} \mathrm{~min}^{-1}\right)$ with that in the periplasmic fraction that was collected during spheroplast preparation $\left(0.002 \mu \mathrm{mol} \mathrm{mg}{ }^{-1} \mathrm{~min}^{-1}\right)$.

With acetate serving as the electron donor, the spheroplasts reduced fumarate, an intracellular electron acceptor (Butler et al., 2006), at a rate comparable to that of intact cells for up to $3 \mathrm{~h}$ (Fig. 1b) but reduced Fe(III) citrate at less than $5 \%$ of the rate of intact cells (Fig. 1c). This result indicated a requirement for periplasmic and/or outer-membrane components for the acetate-dependent reduction of $\mathrm{Fe}(\mathrm{III})$ citrate and was in agreement with previous studies, in which deletion of genes coding for a variety of periplasmic or outer membrane proteins impaired $\mathrm{Fe}$ (III) citrate reduction (Afkar et al., 2005; Butler et al., 2004; Kim et al., 2005, 2006; Leang et al., 2003; Lloyd et al., 2003). Spheroplasts also failed to reduce AQDS with acetate serving as the electron donor (Fig. 1d).

\section{Construction and phenotypic analysis of an SfrAB-null strain}

The evidence described above, which was consistent with reduction of soluble $\mathrm{Fe}(\mathrm{III})$ outside the cytoplasm, did not support the hypothesis that $\mathrm{SfrAB}$ might function as a cytoplasmic Fe(III) reductase (Kaufmann \& Lovley, 2001). In order to further evaluate the physiological function of SfrAB, an SfrAB-null strain $(\triangle s f r A B:: k a n)$ was constructed 
(a)
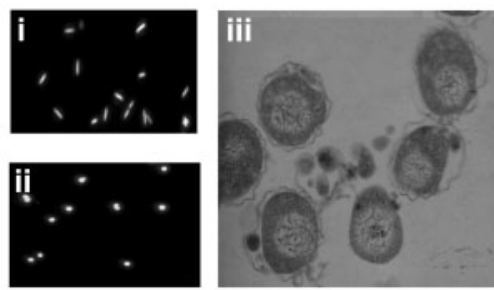

(c)

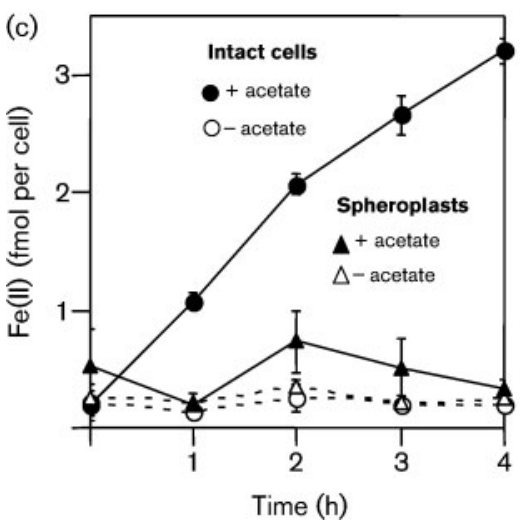

(b)

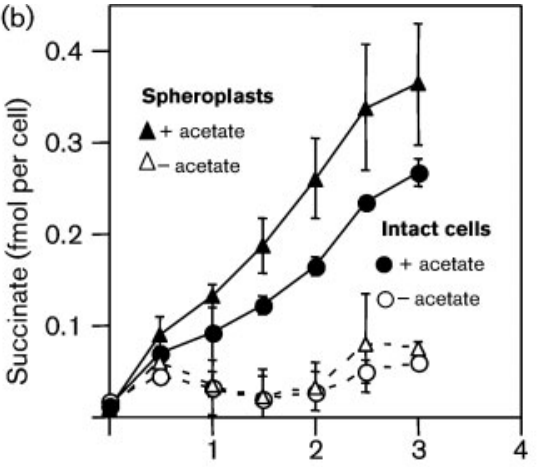

(d)

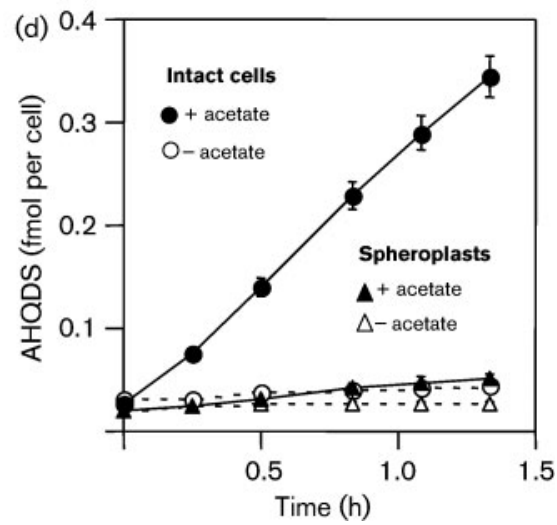

Fig. 1. Properties of G. sulfurreducens spheroplasts. (a) Visual characterization of intact cell and spheroplast suspensions. Acridine orange staining of (i) intact cells and (ii) spheroplast suspensions, and (iii) transmission electron microscopy of thin sections of spheroplasts. (b-d) Acetate-dependent reduction of (b) fumarate, (c) Fe(III) citrate and (d) AQDS by intact cell and spheroplast suspensions. Data are means $\pm S D$ of determinations for triplicate incubations. by replacing $78 \%$ of the $s f r B A$ cluster with a kanamycinresistance cassette by homologous recombination.

Wild-type G. sulfurreducens can utilize acetate as both an electron donor and a carbon source (Caccavo et al. 1994) but cannot exploit either citrate or fumarate for either of these purposes (Esteve-Núñez et al., 2005; Galushko \& Schink, 2000). Both the wild-type and the SfrAB-null strains were able to grow in $\mathrm{Fe}$ (III) citrate medium when either hydrogen or formate was provided as the electron donor (Fig. 2b, c) and a small amount of acetate was provided as a carbon source (1 mM; Coppi et al., 2004). In contrast, only the wild-type strain could grow in $\mathrm{Fe}$ (III) citrate medium when acetate was the sole electron donor and carbon source present (Fig. 2a). A similar phenotype was observed when fumarate served as the electron acceptor (data not shown). The SfrAB-null strain failed to grow in the presence of acetate and fumarate unless an additional electron donor, either hydrogen or formate, was present. These results suggested that SfrAB was not required for $\mathrm{Fe}$ (III) citrate reduction, but was necessary for acetate metabolism, most probably acetate oxidation via the tricarboxylic acid (TCA) cycle (Galushko \& Schink, 2000). Like the wild-type strain (Coppi et al., 2004), the SfrAB-null strain could still utilize acetate as a carbon source during growth via hydrogen- and formate-dependent $\mathrm{Fe}(\mathrm{III})$ reduction.

A specific role for $\mathrm{Sfr} A B$ in acetate oxidation was also supported by comparative genomic analyses. SfrABencoding gene clusters are present exclusively in the genomes of acetate-oxidizing members of the Geobacteraceae, and are notably absent from the genomes of Geobacteraceae belonging to the genus Pelobacter, which can assimilate acetate but cannot use it as an electron donor (Schink, 1984).

\section{Phenotypic characterization of an SfrAB-null strain with the capacity to grow in acetate : fumarate medium}

Two to three weeks after a $1 \%$ transfer of the SfrAB-null mutant from $\mathrm{H}_{2}$ /acetate/fumarate medium into acetate: fumarate medium lacking hydrogen and antibiotics, growth of the SfrAB-null strain was detected. Following this adaptation period, the SfrAB-null strain was able to grow in acetate: fumarate medium with a doubling time and maximum yield that were $118 \pm 13 \%$ and $81 \pm 1.5 \%$, respectively, of those of the wild-type (Fig. 3a). This change in the phenotype of the SfrAB-null strain was stable and was not due to cross-contamination with the wild-type strain (determined by PCR screening with primers FR01 and FRWT) or to reversion of the gene disruption (determined by PCR screening with primers FR01 and FR04; data not shown). The SfrAB-null strain with the capacity to utilize acetate as an electron donor was designated 'acetate-adapted'.

Surprisingly, the acetate-adapted SfrAB-null strain was unable to grow when transferred into acetate:Fe(III) citrate medium (Fig. 3b). Fe(III) reduction by the acetate-adapted SfrAB-null strain was undetectable for up 

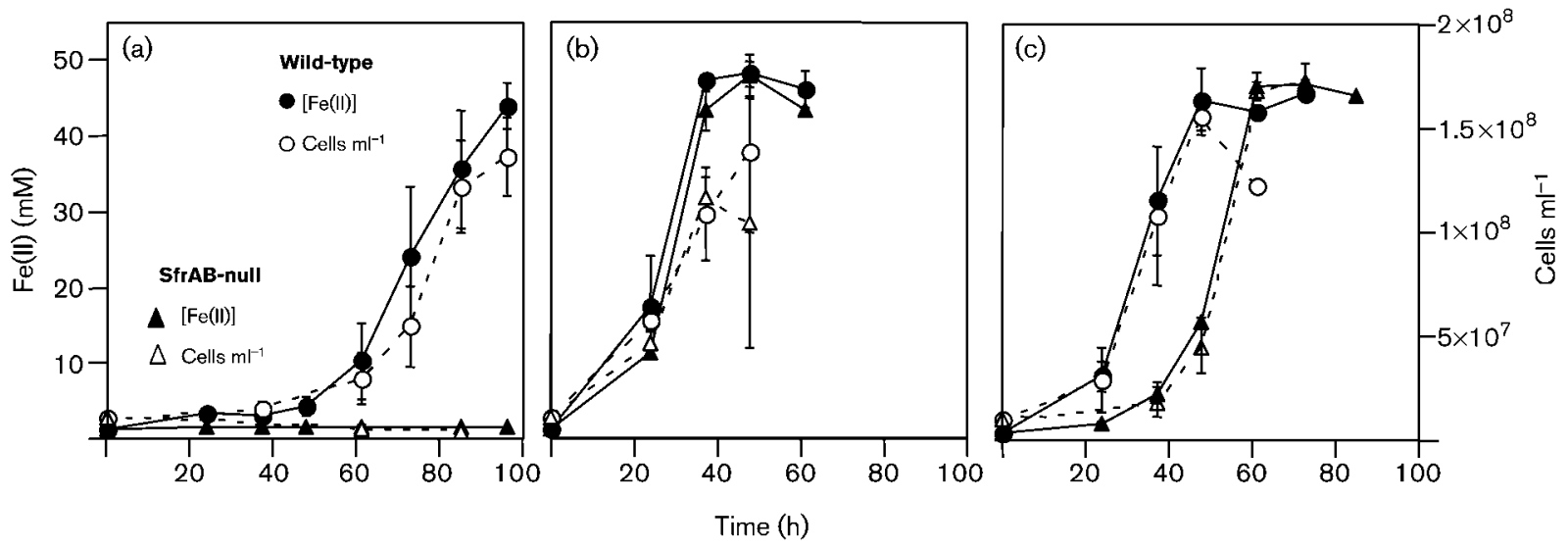

Fig. 2. Growth of wild-type and SfrAB-null strains in Fe(III) citrate medium containing $1 \mathrm{mM}$ acetate as a carbon source and either (a) additional acetate $(9 \mathrm{mM})$, (b) hydrogen $(60 \mathrm{kPa})$ or $(\mathrm{c})$ formate $(40 \mathrm{mM})$ as the electron donor. Exponential-phase cultures growing in acetate:fumarate medium under an $\mathrm{N}_{2}: \mathrm{CO}_{2}$ atmosphere supplemented with $60 \mathrm{kPa}$ hydrogen were pelleted and resuspended in donor-free freshwater Fe(III) citrate medium prior to inoculation for growth studies. Data are means \pm SD of triplicate cultures.

to 2 weeks, whereas the wild-type strain completely reduced the $\mathrm{Fe}$ (III) in the growth medium within $48 \mathrm{~h}$.

The slight reduction in the growth rate and yield of the acetate-adapted SfrAB-null strain in acetate:fumarate medium relative to the wild-type and the inability of the strain to grow in acetate: $\mathrm{Fe}(\mathrm{III})$ citrate medium suggested that the 'acetate-adapted' strain had only partially compensated for the loss of SfrAB and could not metabolize acetate at the wild-type rate. Growth of G. sulfurreducens via $\mathrm{Fe}$ (III) citrate reduction requires a faster rate of acetate oxidation than growth via fumarate reduction. During growth of wild-type G. sulfurreducens in chemostats, the rate of acetate uptake was approximately fourfold higher when $\mathrm{Fe}$ (III) citrate served as the electron acceptor than when fumarate served as the acceptor (Esteve-Núñez et al., 2005). In addition, in silico simulations of central metabolism indicated that, in order to achieve equivalent growth rates, G. sulfurreducens must oxidize acetate three times faster during growth with $\mathrm{Fe}(\mathrm{III})$ citrate relative to growth with fumarate (Mahadevan et al., 2006).

The adaptation phenomenon was reproducible, and the length of the lag phase prior to growth in the absence of hydrogen was inversely proportional to the size of the inoculum. The mechanism by which the SfrAB-null strains developed the ability to grow on acetate was not investigated further. An independently isolated acetateadapted strain was phenotypically and biochemically characterized, with results comparable to those obtained
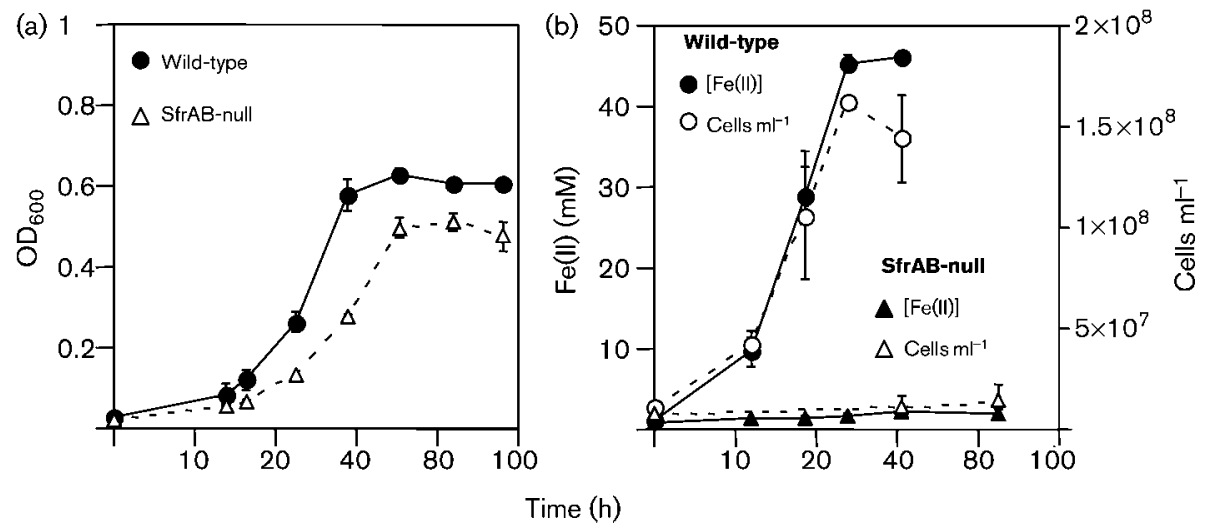

Fig. 3. Growth of the acetate-adapted SfrAB-null and wild-type strains in (a) acetate:fumarate $(10: 40 \mathrm{mM})$ and (b) acetate $: \mathrm{Fe}(\mathrm{III})$ citrate $(10: 55 \mathrm{mM})$ media. Exponential-phase acetate:fumarate cultures of wild-type and acetate-adapted SfrAB-null cultures were washed once in either acetate : fumarate or acetate : Fe(III) citrate medium prior to inoculation. Data are means \pm SD of triplicate cultures. 
for the strain described above (see Supplementary Figs S1 and S2, available with the online version of this paper).

\section{Biochemical characterization of membrane and soluble fractions of the wild-type and acetate-adapted SfrAB-null strains}

In order to gain additional insight into the physiological function of SfrAB, the acetate-adapted SfrAB-null strain was cultured in chemostats at an intermediate growth rate $\left(0.05 \mathrm{~h}^{-1}\right)$ in acetate-limited freshwater fumarate medium ( $5 \mathrm{mM}$ acetate: $27.5 \mathrm{mM}$ fumarate), and cells were harvested for biochemical analysis and mRNA extraction. During growth in chemostats, the cell density of the acetate-adapted SfrAB-null strain was $31 \%$ lower than that of the wild-type $\left(2.88 \pm 0.30 \times 10^{8}\right.$ vs $3.78 \pm 0.88 \times 10^{8}$ cells $\mathrm{ml}^{-1}$ ), whereas the metabolism of acetate and fumarate by the two strains was similar. Acetate was undetectable in the culture media of both strains, and the levels of malate $(9.4 \pm 0.7$ vs $8.3 \pm 0.3 \mathrm{mM})$, succinate $(14.0 \pm 0.7$ vs $14.6 \pm 0.6 \mathrm{mM})$ and fumarate $(5.0 \pm 0.1$ vs $5.6 \pm 1 \mathrm{mM}$ ) were also comparable (data are means \pm SD of triplicate chemostats).

Biochemical analysis of membrane and soluble fractions from chemostat-grown cells (Table 1) demonstrated that elimination of SfrAB greatly decreased the amount of two enzymic activities previously associated with $\mathrm{Sfr} A B$, the NADPH-dependent reduction of Fe(III)-NTA and benzyl viologen (Kaufmann \& Lovley, 2001). A third enzymic activity, NADPH-dependent reduction of AQDS, was also greatly reduced in the SfrAB-null strain (Table 1). Although $\mathrm{SfrAB}$ was previously reported to be a cytoplasmic complex, with $98 \%$ of the activity found in the cytoplasmic fraction (Kaufmann \& Lovley, 2001), in this study $36 \%, 41 \%$ and $57 \%$ of the amount of NADPHdependent $\mathrm{Fe}(\mathrm{III})-\mathrm{NTA}$, benzyl viologen and AQDS reductase activity, respectively, were associated with the membrane fraction (Table 1). This discrepancy did not appear to be due to non-specific contamination of the membrane fraction, as only $0-0.5 \%$ of the activity of three cytoplasmic marker enzymes - pyruvate-ferredoxin oxidoreductase, oxoglutarate ferredoxin-oxidoreductase and malate dehydrogenase - were detected in the membrane fraction. The cause of the discrepancy is not known. Previous failure to detect SfrAB activity in the membrane fraction may have been due to oxygen contamination or to subtle differences in the procedures used to prepare the membrane fractions. In this study, the membrane and soluble fractions were prepared from intact cells and $1 \mathrm{mM}$ magnesium was added to both the wash and lysis buffers, whereas in the previous study (Kaufmann \& Lovley, 2001) the membrane and soluble fractions were prepared from spheroplasts, and neither the spheroplast wash buffer nor the lysis buffer contained magnesium.

Expression of SfrAB from the low-copy-number vector pCDS (Coppi et al., 2001; Leang et al., 2003) resulted in an 8.2 -fold increase in the amount of NADPH-dependent $\mathrm{Fe}(\mathrm{III})-\mathrm{NTA}$ reductase $(0.041 \pm 0.001$ vs $0.005 \pm 0.002$

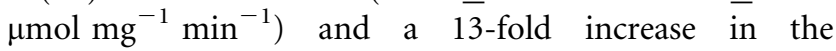
NADPH-dependent $\mathrm{Fe}(\mathrm{III})-\mathrm{NTA}$ reductase $(0.038$ vs $\left.0.507 \pm 0.021 \mu \mathrm{mol} \mathrm{mg}{ }^{-1} \mathrm{~min}^{-1}\right)$ activity present in the soluble fraction of the acetate-adapted SfrAB null strain. Data are mean $\pm \mathrm{SD}$ of triplicate determinations from a soluble fraction prepared from a single mid-exponential culture. The activity of the membrane fraction was not determined.

In summary, deletion of SfrAB caused a dramatic decrease $(\geqslant 98 \%)$ in the NADPH-dependent Fe(III)-NTA, viologen and AQDS reductase activity detected in acetate: fumarategrown G. sulfurreducens and this decrease was partially reversed by expression of the sfrBA cluster in trans. These results suggest that the majority of the $\mathrm{Fe}(\mathrm{III})-\mathrm{NTA}$, viologen and AQDS reductase activity detected in acetate: fumarate-grown G. sulfurreducens may be attributable to SfrAB. In addition, detection of a substantial fraction of these activities in the membrane fraction of wild-type $G$. sulfurreducens indicates that $\mathrm{Sfr} A \mathrm{~B}$ may be peripherally membrane-associated, rather than cytoplasmic, as was previously reported (Kaufmann \& Lovley, 2001).

Sustained acetate oxidation is dependent upon the continuous oxidation of intracellular electron acceptors

Table 1. Enzymic characterization of the membrane and soluble fractions of the wild-type and SfrAB-null strains

\begin{tabular}{|c|c|c|c|c|}
\hline \multirow[t]{2}{*}{ Enzyme } & \multicolumn{4}{|c|}{ Specific activity $\left(\mu \mathrm{mol} \mathrm{mg}{ }^{-1} \min ^{-1}\right)^{\star}$} \\
\hline & $\begin{array}{l}\text { Wild-type/soluble } \\
\text { fraction }\end{array}$ & $\begin{array}{l}\text { Wild-type/membrane fraction } \\
\text { (\% total activity) }\end{array}$ & $\begin{array}{l}\text { SfrAB-null/ } \\
\text { soluble fraction }\end{array}$ & $\begin{array}{l}\text { SfrAB-null/membrane } \\
\text { fraction }\end{array}$ \\
\hline NADPH-dependent Fe(III)NTA reductase & $0.23 \pm 0.02$ & $0.28 \pm 0.05(35.97 \%)$ & $0.005 \pm 0.002$ & $0.004 \pm 0.003$ \\
\hline $\begin{array}{l}\text { NADPH-dependent benzyl viologen } \\
\text { reductase }\end{array}$ & $2.05 \pm 0.05$ & $3.67 \pm 0.05(40.95 \%)$ & $0.038 \pm 0.01$ & 0.00 \\
\hline NADPH-dependent AQDS reductase & $0.087 \pm 0.00$ & $0.254 \pm 0.023(57.5 \%)$ & 0.00 & 0.00 \\
\hline Malate dehydrogenase (NADH dependent) & $18.62 \pm 1.08$ & $0.18 \pm 0.01(0.46 \%)$ & $14.28 \pm 0.21$ & $0.08 \pm 0.02$ \\
\hline Oxoglutarate-ferredoxin oxidoreductase & $1.50 \pm 0.02$ & $0.00(0.00 \%)$ & $1.99 \pm 0.20$ & 0.00 \\
\hline Pyruvate-ferredoxin oxidoreductase & $1.86 \pm 0.16$ & $0.02 \pm 0.00(0.51 \%)$ & $1.82 \pm 0.13$ & $0.01 \pm 0.00$ \\
\hline
\end{tabular}

${ }^{\star}$ Data are means $\pm \mathrm{SD}$ of triplicate determinations. 
including NADPH, as failure to regenerate NADP at an adequate rate would increase the NADPH:NADP ratio and block and/or reverse NADP-dependent reactions including the isocitrate dehydrogenase reaction of the TCA cycle. Inhibition of respiratory growth due to excess $\mathrm{NADPH}$ accumulation has been documented in yeast (Boles et al. 1993; Fiaux et al. 2003; Nissen et al., 2001) and in a strain of $E$. coli lacking the cytoplasmic transhydrogenase UdhA (Sauer et al., 2004). UdhA catalyses the oxidation of NADPH, with NAD serving as the electron acceptor, and is essential for growth of E. coli under two conditions in which the rate of NADPH production exceeds its consumption: growth on glucose in the absence of the phosphoglucose isomerase and growth in minimal medium containing acetate as the sole electron donor and carbon source (Canonaco et al., 2001; Sauer et al., 2004). Thus, one possible explanation for the phenotype of the SfrAB-null strain is that SfrAB serves as a major route for NADP regeneration in G. sulfurreducens. If this were the case, then eliminating SfrAB would elevate the NADPH:NADP ratio and negatively impact acetate oxidation via the TCA cycle. Further research will be required to confirm this hypothesis.

\section{Microarray analysis of the acetate-adapted SfrAB- null strain}

Because identifying genes involved in compensating for the absence of SfrAB might provide additional insights into its physiological function, microarray analysis comparing global gene expression in chemostat cultures of the acetate-adapted SfrAB-null and wild-type strains was performed. RNA for this analysis was isolated from an independent set of triplicate acetate: fumarate chemostats cultured under the conditions described above. Only those genes which were determined to be differentially expressed in the acetate-adapted SfrAB mutant by two statistical methods, SAM (Tusher et al., 2001) and LIMMA (Smyth, 2005 ), and had a fold change in expression of $>1.5$ or $<-1.5$ were considered to be potentially biologically significant. This group of 91 genes consisted of 38 upregulated and 53 downregulated genes (see Supplementary Tables S1 and S2, available with the online version of this paper) and included 25 genes of unknown function as well as the $s f r A$ and $s f r B$ genes, the majority of which $(70-80 \%)$ had been substituted with a kanamycin resistance cassette in the SfrAB-null strain. An overview of these genes and their characteristics is given in the supplementary material available with the online version of this paper (Fig. S3 and Overview and Additional Discussion of Microarray Analysis).

In order to assess the validity of the microarray analysis, the differential expression of 14 genes, including both potentially biologically significant genes and genes predicted to be encoded in operons with such genes, was evaluated by QRT-PCR (Table 2, shown in bold). The RNA used for this analysis was prepared from an independent set of chemostats grown approximately 2 months later than those used for the microarray analysis, specifically those utilized for the biochemical analysis of the membrane and soluble fractions. Differential expression of all but two genes (GSU2706 and GSU1705) was confirmed (Table 2). The biological significance of the 14 genes was evaluated further by comparing their expression in wild-type and SfrAB-null cultures that had been cultured exclusively in the presence of hydrogen (unadapted SfrAB-null), a condition in which $\mathrm{Sfr} A \mathrm{~B}$ is not essential for growth. Ten genes were either not differentially expressed or exhibited a lower level of differential expression during growth in the presence of hydrogen (Table 2, acetate-adapted vs unadapted SfrAB-null). This result suggested that many of the genes identified via microarray analysis might play a role in either compensating for or responding to physiological changes caused by the absence of SfrAB during growth via acetate oxidation.

GSU3057 and GSU3058 were among the most highly upregulated genes identified by microarray analysis. Upregulation of GSU3058 was confirmed by QRT-PCR (Table 2), and upregulation of GSU3057 was confirmed by Northern analysis, which also revealed a transcript size that was consistent with cotranscription of GSU3057 and GSU3058 (data not shown). GSU3057 and GSU3058 were previously annotated as a homotetrameric NADPHdependent glutamate synthase and a putative dihydroorotate electron transfer subunit, respectively (Methé et al., 2003). However, no NADPH-dependent glutamate synthase activity could be detected in either wild-type or acetateadapted SfrAB-null extracts, and GSU3057 and GSU3058 were found to be $65.6 \%$ and $65.2 \%$ similar, respectively, to the $\alpha$ and $\beta$ subunits of the NADPH-dependent ferredoxin oxidoreductase (FNOR) of Pyrococcus furiosus (Ma \& Adams, 1994, 2001; Schut et al., 2003). Phylogenetic analysis of GSU3057 and related proteins, including SfrB, which is $36 \%$ similar, clearly indicated that GSU3057 was more closely related to the $\alpha$ subunit of $P$. furiosus FNOR than to the small subunits of the characterized glutamate synthases (Fig. 4). Thus GSU3057 and GSU3058 are likely to encode an FNOR, and were reannotated accordingly (Table 2).

Northern analysis (data not shown) and QRT-PCR (Table 2) indicated that the putative FNOR was not differentially expressed in the unadapted SfrAB-null strain growing in the presence of hydrogen, which is consistent with a specific role for the FNOR in compensating for the absence of SfrAB during growth via acetate oxidation. If $\mathrm{Sfr} A B$ does, in fact, serve as a major pathway for NADP regeneration during growth of $G$. sulfurreducens via acetate oxidation, the putative FNOR may serve as an alternative route for NADP regeneration and thus play a key role in adaptation of the SfrAB-null strain.

Although the $P$. furiosus FNOR, like SfrAB, also catalyses NADPH-dependent benzyl viologen reduction (Ma \& Adams, 1994, 2001; Schut et al., 2003), the amount of $\mathrm{NADPH}$-dependent benzyl viologen reductase activity in the soluble fraction of the acetate-adapted SfrAB-null strain was less than $1 \%$ of the activity present in the 
Table 2. Differential expression of selected putative operons in the SfrAB-null mutant

\begin{tabular}{|c|c|c|c|c|}
\hline \multirow[t]{2}{*}{ Putative operon ${ }^{\star}$} & \multirow[t]{2}{*}{ Gene: annotation } & \multicolumn{3}{|c|}{ Relative fold change in expression $\dagger$} \\
\hline & & $\begin{array}{l}\text { Acetate-adapted } \\
\text { SfrAB-null vs wild-type } \\
\text { during growth in } \\
\text { acetate : fumarate } \\
\text { chemostats (expt } 1 \text {, } \\
\text { whole-genome } \\
\text { microarray) }\end{array}$ & $\begin{array}{l}\text { Acetate-adapted } \\
\text { SfrAB-null vs wild-type } \\
\text { during growth in acetate : } \\
\text { fumarate chemostats } \\
\text { (expt 2, QRT-PCR) }\end{array}$ & $\begin{array}{l}\text { Unadapted SfrAB-null } \\
\text { vs wild-type during } \\
\text { growth in acetate: } \\
\text { fumarate batch cultures } \\
\text { in the presence of } \mathrm{H}_{2} \\
\text { (QRT-PCR) }\end{array}$ \\
\hline \multirow[t]{7}{*}{ ATP synthase 1} & $\begin{array}{l}\text { GSU0108: putative ATP synthase } \\
\mathrm{F}_{0}, \mathrm{~B}^{\prime} \text { subunit }\end{array}$ & $1.44 \ddagger$ & NA & NA \\
\hline & $\begin{array}{l}\text { GSU0109 (atpF): ATP synthase } \mathrm{F}_{0} \\
\text { B subunit }\end{array}$ & 1.48 & NA & NA \\
\hline & $\begin{array}{l}\text { GSU0110 (atpH): ATP synthase } \mathrm{F}_{1} \\
\delta \text { subunit }\end{array}$ & 1.54 & NA & NA \\
\hline & $\begin{array}{l}\text { GSU0111 }(\operatorname{atpA}) \text { : ATP synthase } \mathrm{F}_{1} \\
\alpha \text { subunit }\end{array}$ & $1.35 \ddagger$ & 3.93 & -1.05 \\
\hline & $\begin{array}{l}\text { GSU0112 (atpG): ATP synthase } \mathrm{F}_{1} \text {, } \\
? \gamma \text { subunit }\end{array}$ & ND & NA & NA \\
\hline & $\begin{array}{l}\text { GSU0113 (atpD): ATP synthase } \mathrm{F}_{1} \text {, } \\
\beta \text { subunit }\end{array}$ & $1.44 \ddagger$ & NA & ND \\
\hline & $\begin{array}{l}\text { GSU0114 }(a t p C) \text { : ATP synthase } \mathrm{F}_{1} \text {, } \\
\varepsilon ? \text { subunit }\end{array}$ & ND & NA & ND \\
\hline \multirow[t]{2}{*}{ ATP synthase 2} & $\begin{array}{l}\text { GSU0333 (atpE): ATP synthase } \mathrm{F}_{0} \\
\text { C subunit }\end{array}$ & 1.67 & NA & NA \\
\hline & $\begin{array}{l}\text { GSU0334 (atpF): ATP synthase } \mathrm{F}_{0} \\
\text { A subunit }\end{array}$ & ND & NA & NA \\
\hline \multirow[t]{4}{*}{ Formate dehydrogenase } & GSU0777 ( $f d h G)$ : catalytic subunit & $1.31 \ddagger$ & NA & NA \\
\hline & $\begin{array}{l}\text { GSU0778 }(f d n H) \text { : iron-sulfur } \\
\text { subunit }\end{array}$ & 1.46 & 1.92 & 1.46 \\
\hline & $\begin{array}{l}\text { GSU0779: integral membrane } \\
\text { subunit }\end{array}$ & $1.6 \ddagger$ & NA & NA \\
\hline & $\begin{array}{l}\text { GSU0780 }(f d h D) \text { : accessory } \\
\text { protein }\end{array}$ & ND & NA & NA \\
\hline \multirow[t]{5}{*}{ Respiratory hydrogenase } & GSU0782 (hybS): small subunit & ND & NA & NA \\
\hline & $\begin{array}{l}\text { GSU0783 (hybA): iron-sulfur } \\
\text { subunit }\end{array}$ & 1.65 & NA & NA \\
\hline & $\begin{array}{l}\text { GSU0784 (hybB): integral } \\
\text { membrane subunit }\end{array}$ & ND & NA & NA \\
\hline & GSU0785 (hybL): large subunit & 1.62 & 2.89 & 1.44 \\
\hline & $\begin{array}{l}\text { GSU0786 }(h y b P) \text { : maturation } \\
\text { protease }\end{array}$ & ND & $\mathrm{NA}$ & $\mathrm{NA}$ \\
\hline $\begin{array}{l}\text { Monocistronic } \\
\text { transcription unit }\end{array}$ & $\begin{array}{l}\text { GSU1024 }(p p c D) \text { periplasmic } \\
\text { trihaem cytochrome } c\end{array}$ & 1.73 & NA & NA \\
\hline \multirow[t]{2}{*}{$\begin{array}{l}\text { Sodium/monocarboxylate } \\
\text { symporter }\end{array}$} & $\begin{array}{l}\text { GSU1068 (actP): sodium/ } \\
\text { monocarboxylate symporter }\end{array}$ & -1.58 & -2.05 & 1.08 \\
\hline & $\begin{array}{l}\text { GSU1069: conserved hypothetical } \\
\text { protein }\end{array}$ & $-1.4 \ddagger$ & NA & NA \\
\hline $\begin{array}{l}\text { Monocistronic } \\
\text { transcription unit }\end{array}$ & $\begin{array}{l}\text { GSU1379 (fur): ferric uptake } \\
\text { regulator }\end{array}$ & -2.11 & -1.76 & -1.64 \\
\hline \multirow[t]{5}{*}{$\begin{array}{l}\text { Geopilin/unknown } \\
\text { function }\end{array}$} & $\begin{array}{l}\text { GSU1496 (pilA): geopilin } \\
\text { structural subunit }\end{array}$ & 6.83 & 1.54 & -6.87 \\
\hline & GSU1497: hypothetical protein & 6.36 & NA & NA \\
\hline & $\begin{array}{l}\text { GSU1498: putative membrane } \\
\text { protein }\end{array}$ & 5.13 & NA & NA \\
\hline & $\begin{array}{l}\text { GSU1499: putative membrane } \\
\text { protein }\end{array}$ & 2.59 & NA & NA \\
\hline & GSU1500: hypothetical protein & 1.9 & NA & NA \\
\hline
\end{tabular}


Table 2. cont.

\begin{tabular}{|c|c|c|c|c|}
\hline \multirow[t]{2}{*}{ Putative operon ${ }^{\star}$} & \multirow[t]{2}{*}{ Gene: annotation } & \multicolumn{3}{|c|}{ Relative fold change in expression $\dagger$} \\
\hline & & $\begin{array}{l}\text { Acetate-adapted } \\
\text { SfrAB-null vs wild-type } \\
\text { during growth in } \\
\text { acetate : fumarate } \\
\text { chemostats (expt } 1 \text {, } \\
\text { whole-genome } \\
\text { microarray) }\end{array}$ & $\begin{array}{l}\text { Acetate-adapted } \\
\text { SfrAB-null vs wild-type } \\
\text { during growth in acetate: } \\
\text { fumarate chemostats } \\
\text { (expt 2, QRT-PCR) }\end{array}$ & $\begin{array}{l}\text { Unadapted SfrAB-null } \\
\text { vs wild-type during } \\
\text { growth in acetate: } \\
\text { fumarate batch cultures } \\
\text { in the presence of } \mathrm{H}_{2} \\
\text { (QRT-PCR) }\end{array}$ \\
\hline \multirow[t]{3}{*}{$\begin{array}{l}\text { Panthothenate } \\
\text { biosynthesis }\end{array}$} & $\begin{array}{l}\text { GSU1705 (panB): } \\
\text { 3-methyl-2-oxobutanoate } \\
\text { hydroxylmethyltransferase }\end{array}$ & -1.45 & -1.01 & -1.64 \\
\hline & $\begin{array}{l}\text { GSU1706 (panC): } \\
\text { pantoate- } \beta \text {-alanine ligase }\end{array}$ & -1.65 & NA & NA \\
\hline & GSU1707: group II decarboxylase & -1.50 & NA & NA \\
\hline $\begin{array}{l}\text { Monocistronic } \\
\text { transcription unit }\end{array}$ & GSU2076: cytochrome $c$ & 1.6 & $\mathrm{NA}$ & $\mathrm{NA}$ \\
\hline $\begin{array}{l}\text { Monocistronic } \\
\text { transcription unit }\end{array}$ & $\begin{array}{l}\text { GSU2490: carboxylate exchanger } \\
\text { of unknown specificity }\end{array}$ & 2.19 & 20.25 & 1.17 \\
\hline \multirow[t]{2}{*}{$\begin{array}{l}\text { Outer-membrane } \\
\text { cytochrome } \$\end{array}$} & $\begin{array}{l}\text { GSU2503 (omcT): outer-mem- } \\
\text { brane } c \text {-type cytochrome }\end{array}$ & ND & NA & NA \\
\hline & $\begin{array}{l}\text { GSU2504 }(\mathrm{omcS}) \text { : outer-mem- } \\
\text { brane } c \text {-type cytochrome }\end{array}$ & 4.97 & NA & NA \\
\hline $\begin{array}{l}\text { Monocistronic } \\
\text { transcription unit }\end{array}$ & $\begin{array}{l}\text { GSU2706: phosphate acetyl } \\
\text { transferase }\end{array}$ & -1.55 & 1.33 & -1.05 \\
\hline \multirow[t]{3}{*}{ OmcB operonll } & $\begin{array}{l}\text { GSU2737: } o m c B \text {, cytochrome } c \\
\text { family protein }\end{array}$ & 2.43 & 1.52 & -11.20 \\
\hline & $\begin{array}{l}\text { GSU2738 (orf2-1): cytochrome } c \\
\text { family protein }\end{array}$ & ND & $\mathrm{NA}$ & NA \\
\hline & $\begin{array}{l}\text { GSU2739 (orf1-1): hypothetical } \\
\text { protein }\end{array}$ & 2.2 & $\mathrm{NA}$ & $\mathrm{NA}$ \\
\hline \multirow{2}{*}{$\begin{array}{l}\text { NADPH-dependent } \\
\text { ferredoxin oxidoreductase }\end{array}$} & GSU3057: fnpA, $\alpha$ subunit & 5.84 & NA & NA \\
\hline & GSU3058: $f n p B, \beta$ subunit & 2.85 & 5.39 & -1.07 \\
\hline \multirow{2}{*}{$\begin{array}{l}\text { Chorismate biosynthesis/ } \\
\text { unknown }\end{array}$} & GSU3141: hypothetical protein & 2.91 & NA & NA \\
\hline & $\begin{array}{l}\text { GSU3142: aroF, phospho-2-dehy- } \\
\text { dro-3-deoxyheptonate aldolase }\end{array}$ & 3.02 & 3.70 & -1.04 \\
\hline \multirow[t]{6}{*}{$\begin{array}{l}\text { Amino acid } \mathrm{ABC} \\
\text { transporter }\end{array}$} & $\begin{array}{l}\text { GSU3401: periplasmic amino acid } \\
\text { binding protein }\end{array}$ & 7.09 & 2.61 & 1.25 \\
\hline & GSU3402: hypothetical protein & ND & $\mathrm{NA}$ & NA \\
\hline & $\begin{array}{l}\text { GSU3403: hypothetical protein, } \\
\text { potential porin }\end{array}$ & 5.5 & $\mathrm{NA}$ & $\mathrm{NA}$ \\
\hline & GSU3404: ATP-binding protein & 4.25 & $\mathrm{NA}$ & NA \\
\hline & GSU3405: permease & 1.86 & $\mathrm{NA}$ & $\mathrm{NA}$ \\
\hline & $\begin{array}{l}\text { GSU3406: periplasmic amino acid } \\
\text { binding protein }\end{array}$ & 7.45 & 2.13 & 1.05 \\
\hline
\end{tabular}

${ }^{*}$ Operon predictions are based on homology to characterized operons or using the FGENESB software (www.softberry.com) as previously described (Yan et al., 2004).

$\dagger$ Relative fold changes for whole-genome microarray data were estimated via LIMMA analysis as described in Methods. ND indicates that statistically significant differential expression was not detected in the microarray. For QRT-PCR data, relative fold changes in expression were determined using the $2^{-\Delta \Delta C T}$ method (Livak \& Schmittgen, 2001) and are the mean of triplicate determinations. NA indicates that QRT-PCR analysis was not performed for a particular gene.

¥These genes did not make the stringent statistical and fold-change cutoffs for differential expression described in Methods but were identified as differentially expressed by one of the two statistical approaches that were employed, either LIMMA or SAM.

$\S o m c S$ can be transcribed either monocistronically or in conjunction with omcT (Mehta et al., 2005).

IIThe $o m c B$ operon has been experimentally confirmed (Leang \& Lovley, 2005). 


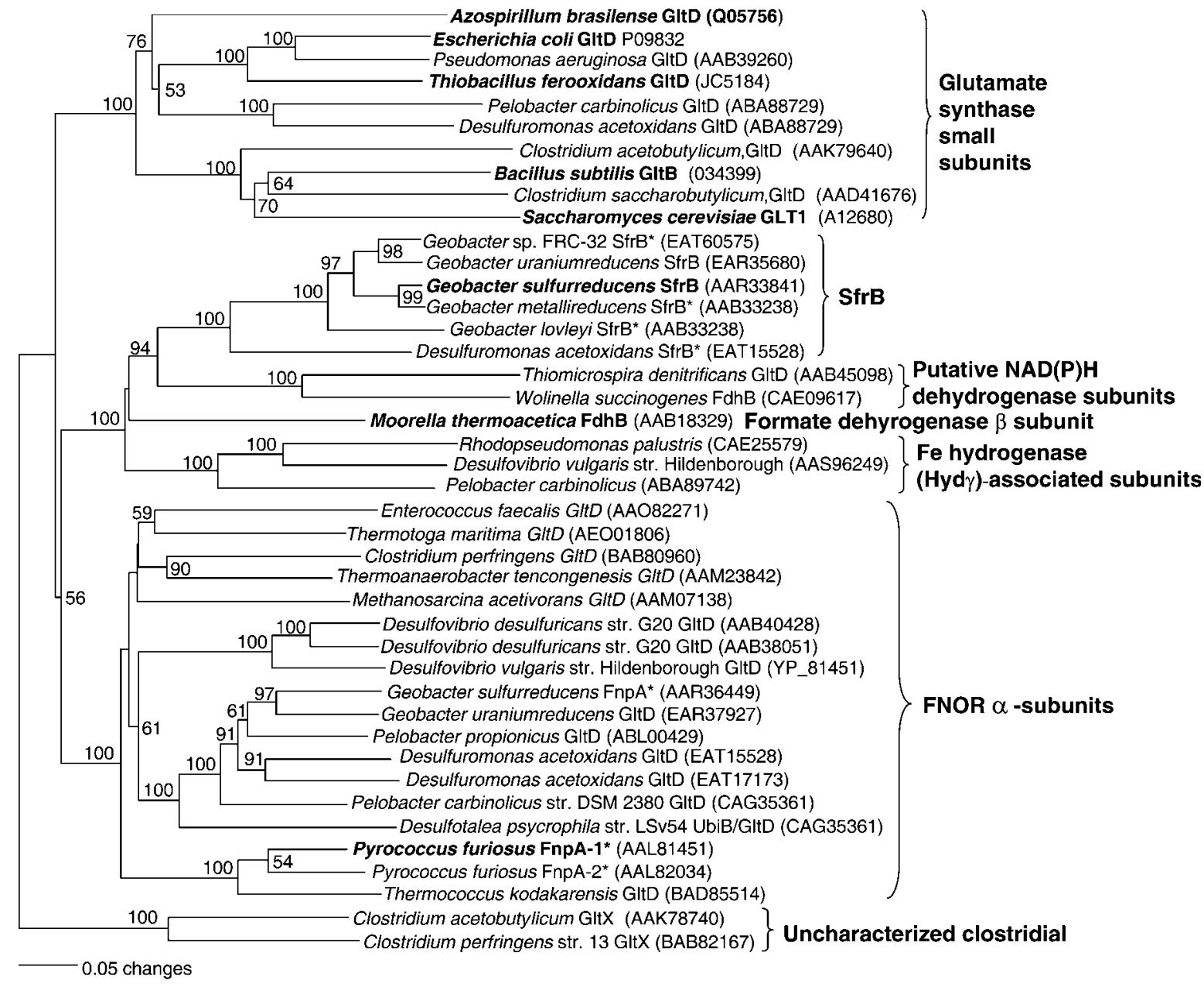

Fig. 4. Phylogenetic analysis of NADPH-oxidizing subunits related to SfrB and GSU3057. Distances and branching order were determined for protein sequences by the neighbour-joining method (Saitou \& Nei, 1987) using the BioNJ algorithm (Gascuel, 1997) as previously described (Coppi, 2005), and bootstrap values were determined for 100 replicates. Biochemically and/or genetically characterized genes are indicated in bold, accession numbers are in parentheses and * indicates that the gene symbol was assigned by the authors. The majority of the proteins included in this phylogenetic tree are annotated as glutamate synthase small subunits in the NCBI database regardless of their degree of homology to characterized proteins (Stutz \& Reid, 2004) or the identity of neighbouring genes. The genes for all proteins within the glutamate synthase small subunit cluster are adjacent to genes homologous to characterized glutamate synthase large subunit genes, with the exception of GLT1 of Saccharomyces cerevisiae, in which the large and small subunits constitute distinct domains within a single peptide. Likewise the genes for all members of the SfrB and FNOR $\alpha$ subunit clusters are adjacent to sfrA and FNOR $\beta$ subunit homologues, respectively. Members of the Fe-hydrogenase ( $\mathrm{Hyd} \gamma)$-associated subunit cluster are encoded adjacent to homologues of the putative Fe-hydrogenase of Desulfuvibrio vulgaris, $\mathrm{Hyd} \gamma$, whereas the putative $\mathrm{NAD}(\mathrm{P}) \mathrm{H}$ dehydrogenase subunits are encoded in clusters that contain multiple genes that are homologous to the various subunits of NADH dehydrogenases.

wild-type strain. The apparent lack of FNOR activity in the adapted mutant despite a three- to sixfold increase in the level of its putative transcripts could have several possible explanations, including insufficient expression despite elevated mRNA levels, post-transcriptional regulation, or differences in the activity, stability or substrate specificity of the putative G. sulfurreducens FNOR relative to that of $P$. furiosus. Alternatively, GSU3057 and GSU3058 may not encode a FNOR at all.
Additional study will clearly be required to elucidate the substrate specificity and physiological function of the complex consisting of GSU3057 and GSU3058. Nevertheless, the fact that two of the most highly upregulated genes in the acetate-adapted SfrAB-null strain appear to encode a complex with NADPH oxidoreductase activity is consistent with a role for SfrAB in influencing NADP concentrations, which in turn would affect acetate oxidation via the TCA cycle. 
Several genes involved in energy generation and amino acid uptake and biosynthesis were also upregulated in the 'acetate-adapted SfrAB-null strain'. These included a putative polar and branched-chain amino acid $A B C$ transporter, an enzyme catalysing a critical step in aromatic amino acid biosynthesis, the operons encoding the $\mathrm{F}_{1} \mathrm{~F}_{0}$ ATPase and a variety of redox-active proteins, including the structural subunit of the electroconductive pili of $G$. sulfurreducens (Reguera et al., 2005) (see Table 2 and the supplementary Overview and Additional Discussion of Microarray Analysis for additional details). Because both energy generation and amino acid biosynthesis are dependent upon acetate oxidation via the TCA cycle (Galushko \& Schink, 2000; Mahadevan et al., 2006; Reitzer, 2006), upregulation of these genes may be an indication that flux through the TCA cycle was insufficient to fulfil both the energetic and biosynthetic needs of the acetateadapted SfrAB-null strain. Many of these genes were not upregulated during growth of the unadapted SfrAB-null strain on hydrogen (Table 2), which is consistent with a specific role for these genes in growth on acetate in the absence of SfrAB.

\section{Implications}

This study indicates that although $\mathrm{SfrAB}$ was purified as an $\mathrm{Fe}(\mathrm{III})$ reductase and catalyses NADPH-dependent $\mathrm{Fe}(\mathrm{III})$ reduction in vitro (Kaufmann \& Lovley, 2001), it does not function as an $\mathrm{Fe}(\mathrm{III})$ reductase in vivo. Intact and metabolically active spheroplasts could not carry out acetate-dependent $\mathrm{Fe}(\mathrm{III})$ citrate reduction, indicating that proteins beyond the cytoplasm and cytoplasmic surface of the inner membrane, where SfrAB is likely to be found, are required for $\mathrm{Fe}$ (III) citrate reduction. In addition, characterization of an SfrAB-null strain indicated that SfrAB was involved in acetate metabolism. Immediately following isolation, the SfrAB-null strain was unable to grow in medium containing acetate as the sole electron donor and carbon source but retained the ability to grow with the alternative electron donors hydrogen and formate if a small amount of acetate was provided as a carbon source. Although the SfrAB-null strain eventually developed the ability to grow on acetate with fumarate as the electron acceptor, growth with $\mathrm{Fe}(\mathrm{III})$ citrate as the electron acceptor, which requires faster rates of acetate oxidation, was not achieved.

The lack of a direct role for $\mathrm{SfrAB}$ in $\mathrm{Fe}(\mathrm{III})$ citrate reduction is not surprising given that Geobacter species normally grow in subsurface environments where the majority of $\mathrm{Fe}(\mathrm{III})$ is in the form of insoluble $\mathrm{Fe}(\mathrm{III})$ oxides (Amonette, 2002; Lovley et al., 2004) and that they possibly synthesize a variety of specialized proteins and structures for exploiting extracellular electron acceptors, including electroconductive pili (Mehta et al., 2005, 2006; Reguera et al., 2005). The purification and characterization of SfrAB as an $\mathrm{Fe}$ (III) reductase took place before a genetic system for analysing gene function in G. sulfurreducens was readily available. In the search for $\mathrm{Fe}$ (III) reductases, the genetic approach may be superior to a strictly biochemical approach because many enzymes, particularly those with flavin cofactors or flavin-reductase acitivity, may non-specifically reduce $\mathrm{Fe}$ (III) in vitro (Filisetti et al., 2005; Fischer et al., 2002; Petrat et al., 2003; Schroder et al., 2003). In light of these results, previous studies describing the purification of membrane-bound complexes that had NADH-dependent $\mathrm{Fe}(\mathrm{III})$ reductase activity and contained both cytochromes and flavin cofactors (Gaspard et al., 1998; Magnuson et al., 2000) should be interpreted with caution.

Differences in gene expression between the acetate-adapted SfrAB-null and wild-type strains suggested that knocking out SfrAB caused substantial changes in the metabolic state of G. sulfurreducens. The apparent upregulation of a putative NADPH-dependent ferredoxin oxidoreductase in the acetate-adapted SfrAB-null strain suggested that SfrAB might play a role in regulating the intracellular NADPH:NADP ratio, as did the discovery that deletion of SfrAB caused a dramatic decrease in the amount of $\mathrm{NADPH}$-dependent benzyl viologen reductase activity in G. sulfurreducens. Because continuous regeneration of NADP is critical for flux through the TCA cycle, it is possible that deleting SfrAB impacted acetate metabolism by perturbing the NADPH : NADP ratio. Given that acetate fuels the growth of Geobacter species in many soils and sediments (Lovley et al., 2004), and homologues of SfrAB are encoded in the genomes of all acetate-oxidizing Geobacter species sequenced to date, further investigation of the role of SfrAB in acetate metabolism is warranted.

\section{ACKNOWLEDGEMENTS}

This research was supported by grant DE-FC02-02ER63446 from the Genomics:GTL Program of the Office of Science (BER), US Department of Energy. We would like to thank Shelley Haveman, Laurie DiDonato, Chingheang and Carla Risso for their assistance in editing this manuscript.

\section{REFERENCES}

Afkar, E., Reguera, G., Schiffer, M. \& Lovley, D. R. (2005). A novel Geobacteraceae-specific outer membrane protein J (OmpJ) is essential for electron transport to $\mathrm{Fe}(\mathrm{III})$ and $\mathrm{Mn}(\mathrm{IV})$ oxides in Geobacter sulfurreducens. BMC Microbiol 5, 41.

Amonette, J. E. (2002). Iron redox chemistry of clays and oxides: environmental applications. In Electrochemical Properties of Clays (CMS Workshop Lectures vol. 10), pp. 89-147. Edited by A. Fitch. Aurora, CO: The Clay Minerals Society.

Boles, E., Lehnert, W. \& Zimmermann, F. K. (1993). The role of NADdependent glutamate dehydrogenase in restoring growth on glucose of a Saccharomyces cerevisiae phosphoglucose isomerase mutant. Eur J Biochem 217, 469-477.

Brandis-Heep, A., Gebhardt, N. A., Thauer, R. K., Widdel, F. \& Pfennig, N. (1983). Anaerobic acetate oxidation to $\mathrm{CO}_{2}$ by Desulfobacter postgatei. Arch Microbiol 136, 222-229.

Butler, J. E., Kaufmann, F., Coppi, M. V., Núñez, C. \& Lovley, D. R. (2004). MacA, a diheme c-type cytochrome involved in $\mathrm{Fe}(\mathrm{III})$ reduction by Geobacter sulfurreducens. J Bacteriol 186, 4042-4045. 
Butler, J. E., Glaven, R. H., Esteve-Núñez, A., Núñez, C., Shelobolina, E. S., Bond, D. R. \& Lovley, D. R. (2006). Genetic characterization of a single bifunctional enzyme for fumarate reduction and succinate oxidation in Geobacter sulfurreducens and engineering of fumarate reduction in Geobacter metallireducens. J Bacteriol 188, 450-455.

Caccavo, F., Jr, Lonergan, D. J., Lovley, D. R., Davis, M., Stolz, J. F. \& Mclnerney, M. J. (1994). Geobacter sulfurreducens sp. nov., a hydrogen- and acetate-oxidizing dissimilatory metal-reducing microorganism. Appl Environ Microbiol 60, 3752-3759.

Canonaco, F., Hess, T. A., Heri, S., Wang, T., Szyperski, T. \& Sauer, U. (2001). Metabolic flux response to phosphoglucose isomerase knockout in Escherichia coli and impact of overexpression of the soluble transhydrogenase UdhA. FEMS Microbiol Lett 204, 247-252.

Coppi, M. V. (2005). The hydrogenases of Geobacter sulfurreducens: a comparative genomic perspective. Microbiology 151, 1239-1254.

Coppi, M. V., Leang, C., Sandler, S. J. \& Lovley, D. R. (2001). Development of a genetic system for Geobacter sulfurreducens. Appl Environ Microbiol 67, 3180-3187.

Coppi, M. V., O'Neil, R. A. \& Lovley, D. R. (2004). Identification of an uptake hydrogenase required for hydrogen-dependent reduction of $\mathrm{Fe}$ (III) and other electron acceptors by Geobacter sulfurreducens. J Bacteriol 186, 3022-3028.

DiDonato, L. N., Sullivan, S. A., Methé, B. A., Nevin, K. P., England, R. \& Lovley, D. R. (2006). Role of $\operatorname{Rel}_{G s u}$ in stress response and $\mathrm{Fe}(\mathrm{III})$ reduction in Geobacter sulfurreducens. J Bacteriol 188, 8469-8478.

Ding, Y. H., Hixson, K. K., Giometti, C. S., Stanley, A., Esteve-Núñez, A., Khare, T., Tollaksen, S. L., Zhu, W., Adkins, J. N. \& other authors (2006). The proteome of dissimilatory metal-reducing microorganism Geobacter sulfurreducens under various growth conditions. Biochim Biophys Acta 1764, 1198-1206.

Esteve-Núñez, A., Rothermich, M., Sharma, M. \& Lovley, D. R. (2005). Growth of Geobacter sulfurreducens under nutrient-limiting conditions in continuous culture. Environ Microbiol 7, 641-648.

Fiaux, J., Cakar, Z. P., Sonderegger, M., Wuthrich, K., Szyperski, T. \& Sauer, U. (2003). Metabolic-flux profiling of the yeasts Saccharomyces cerevisiae and Pichia stipitis. Eukaryot Cell 2, 170-180.

Filisetti, L., Valton, J., Fontecave, M. \& Niviere, V. (2005). The flavin reductase ActVB from Streptomyces coelicolor: characterization of the electron transferase activity of the flavoprotein form. FEBS Lett $\mathbf{5 7 9}$, 2817-2820.

Fischer, F., Raimondi, D., Aliverti, A. \& Zanetti, G. (2002). Mycobacterium tuberculosis FprA, a novel bacterial NADPH-ferredoxin reductase. Eur J Biochem 269, 3005-3013.

Galushko, A. S. \& Schink, B. (2000). Oxidation of acetate through reactions of the citric acid cycle by Geobacter sulfurreducens in pure culture and in syntrophic coculture. Arch Microbiol 174, 314-321.

Gascuel, O. (1997). BIONJ: an improved version of the NJ algorithm based on a simple model of sequence data. Mol Biol Evol 14, 685-695.

Gaspard, S., Vazquez, F. \& Holliger, C. (1998). Localization and solubilization of the Iron(III) reductase of Geobacter sulfurreducens. Appl Environ Microbiol 64, 3188-3194.

Kaufmann, F. \& Lovley, D. R. (2001). Isolation and characterization of a soluble NADPH-dependent $\mathrm{Fe}(\mathrm{III})$ reductase from Geobacter sulfurreducens. J Bacteriol 183, 4468-4476.

Kim, B. C., Leang, C., Ding, Y. H., Glaven, R. H., Coppi, M. V. \& Lovley, D. R. (2005). OmcF, a putative $c$-type monoheme outer membrane cytochrome required for the expression of other outer membrane cytochromes in Geobacter sulfurreducens. J Bacteriol 187, 4505-4513.

Kim, B. C., Qian, X., Leang, C., Coppi, M. V. \& Lovley, D. R. (2006). Two putative c-type multiheme cytochromes required for the expression of $\mathrm{OmcB}$, an outer membrane protein essential for optimal Fe(III) reduction in Geobacter sulfurreducens. J Bacteriol 188, 3138-3142.

Kovach, M. E., Phillips, R. W., Elzer, P. H., Roop, R. M., II \& Peterson, K. M. (1994). pBBR1MCS: a broad-host-range cloning vector. Biotechniques 16, 800-802.

Leang, C. \& Lovley, D. R. (2005). Regulation of two highly similar genes, $o m c B$ and $o m c C$, in a $10 \mathrm{~kb}$ chromosomal duplication in Geobacter sulfurreducens. Microbiology 151, 1761-1767.

Leang, C., Coppi, M. V. \& Lovley, D. R. (2003). OmcB, a c-type polyheme cytochrome, involved in $\mathrm{Fe}(\mathrm{III})$ reduction in Geobacter sulfurreducens. J Bacteriol 185, 2096-2103.

Livak, K. J. \& Schmittgen, T. D. (2001). Analysis of relative gene expression data using real-time quantitative PCR and the $2^{-\Delta \Delta C T}$ method. Methods 25, 402-408.

Lloyd, J. R., Leang, C., Hodges Myerson, A. L., Coppi, M. V., Cuifo, S., Methé, B., Sandler, S. J. \& Lovley, D. R. (2003). Biochemical and genetic characterization of PpcA, a periplasmic $c$-type cytochrome in Geobacter sulfurreducens. Biochem J 369, 153-161.

Lovley, D. R. (2006). Bug juice: harvesting electricity with microorganisms. Nature Reviews 4, 497-508.

Lovley, D. R. \& Phillips, E. J. P. (1988). Novel mode of microbial energy metabolism: organic carbon oxidation coupled to dissimilatory reduction of iron or manganese. Appl Environ Microbiol 54, 1472-1480.

Lovley, D. R., Giovannoni, S. J., White, D. C., Champine, J. E., Phillips, E. J., Gorby, Y. A. \& Goodwin, S. (1993). Geobacter metallireducens gen. nov. sp. nov., a microorganism capable of coupling the complete oxidation of organic compounds to the reduction of iron and other metals. Arch Microbiol 159, 336-344.

Lovley, D. R., Coates, J. D., Blunt-Harris, E. L., Phillips, E. J. P. \& Woodward, J. C. (1996). Humic substances as electron acceptors for microbial respiration. Nature 382, 445-447.

Lovley, D. R., Holmes, D. E. \& Nevin, K. P. (2004). Dissimilatory $\mathrm{Fe}(\mathrm{III})$ and $\mathrm{Mn}(\mathrm{IV})$ reduction. Adv Microb Physiol 49, 219-286.

Ma, K. \& Adams, M. W. (1994). Sulfide dehydrogenase from the hyperthermophilic archaeon Pyrococcus furiosus: a new multifunctional enzyme involved in the reduction of elemental sulfur. J Bacteriol 176, 6509-6517.

Ma, K. \& Adams, M. W. (2001). Ferredoxin : NADP oxidoreductase from Pyrococcus furiosus. Methods Enzymol 334, 40-45.

Magnuson, T. S., Hodges-Myerson, A. L. \& Lovley, D. R. (2000). Characterization of a membrane-bound NADH-dependent $\mathrm{Fe}^{(3+)}$ reductase from the dissimilatory $\mathrm{Fe}^{(3+)}$-reducing bacterium Geobacter sulfurreducens. FEMS Microbiol Lett 185, 205-211.

Mahadevan, R., Bond, D. R., Butler, J. E., Esteve-Núñez, A., Palsson, A. B. O., Schilling, C. H., Coppi, M. V. \& Lovley, D. R. (2006). Characterization of metabolism in the $\mathrm{Fe}(\mathrm{III})$ reducing organism, Geobacter sulfurreducens, by constraint-based modeling. Appl Environ Microbiol 72, 1558-1568.

Mehta, T., Coppi, M. V., Childers, S. E. \& Lovley, D. R. (2005). Outer membrane $c$-type cytochromes required for $\mathrm{Fe}(\mathrm{III})$ and $\mathrm{Mn}$ (IV) oxide reduction in Geobacter sulfurreducens. Appl Environ Microbiol 71, 8634-8641.

Mehta, T., Childers, S. E., Glaven, R., Lovley, D. R. \& Mester, T. (2006). A putative multicopper protein secreted by an atypical type II secretion system involved in the reduction of insoluble electron acceptors in Geobacter sulfurreducens. Microbiology 152, 2257-2264.

Methé, B. A., Nelson, K. E., Eisen, J. A., Paulsen, I. T., Nelson, W., Heidelberg, J. F., Wu, D., Wu, M., Ward, N. \& other authors (2003). Genome of Geobacter sulfurreducens: metal reduction in subsurface environments. Science 302, 1967-1969. 
Methé, B. A., Webster, J., Nevin, K., Butler, J. \& Lovley, D. R. (2005). DNA microarray analysis of nitrogen fixation and Fe(III) reduction in Geobacter sulfurreducens. Appl Environ Microbiol 71, 2530-2538.

Nevin, K. P. \& Lovley, D. R. (2000). Lack of production of electronshuttling compounds or solubilization of Fe(III) during reduction of insoluble Fe(III) oxide by Geobacter metallireducens. Appl Environ Microbiol 66, 2248-2251.

Nissen, T. L., Anderlund, M., Nielsen, J., Villadsen, J. \& KiellandBrandt, M. C. (2001). Expression of a cytoplasmic transhydrogenase in Saccharomyces cerevisiae results in formation of 2-oxoglutarate due to depletion of the NADPH pool. Yeast 18, 19-32.

Núñez, C., Adams, L., Childers, S. \& Lovley, D. R. (2004). The RpoS sigma factor in the dissimilatory $\mathrm{Fe}(\mathrm{III})$-reducing bacterium Geobacter sulfurreducens. J Bacteriol 186, 5543-5546.

Núñez, C., Esteve-Núñez, A., Giometti, C., Tollaksen, S., Khare, T. Lin, W., Lovley, D. R. \& Methé, B. A. (2006). DNA microarray and proteomic analyses of the RpoS regulon in Geobacter sulfurreducens. J Bacteriol 188, 2792-2800.

Petrat, F., Paluch, S., Dogruoz, E., Dorfler, P., Kirsch, M., Korth, H. G., Sustmann, R. \& de Groot, H. (2003). Reduction of $\mathrm{Fe}(\mathrm{III})$ ions complexed to physiological ligands by lipoyl dehydrogenase and other flavoenzymes in vitro: implications for an enzymatic reduction of $\mathrm{Fe}(\mathrm{III})$ ions of the labile iron pool. J Biol Chem 278, 46403-46413.

Reeves, H. C., Rabin, R., Wegener, W. S. \& Ajl, J. (1971). Assays of enzymes of the tricarboxylic and glyoxylate cycles. Methods Microbiol 6A, 425-462.

Reguera, G., McCarthy, K. D., Mehta, T., Nicoll, J. S., Tuominen, M. T. \& Lovley, D. R. (2005). Extracellular electron transfer via microbial nanowires. Nature 435, 1098-1101.

Reitzer, L. (2006). Biosynthesis of glutamate, aspartate, asparagine, Lalanine, and D-alanine In EcoSal-Escherichia coli and Salmonella: Cellular and Molecular Biology [Online] http://www.ecosal.org. Edited by A. Böck, R. Curtiss III, J. B. Kaper, F. C. Neidhardt, T. Nyström, E. Rudd \& C. L. Squires. Washington, DC: American Society for Microbiology.

Saitou, N. \& Nei, M. (1987). The neighbor-joining method: a new method for reconstructing phylogenetic trees. Mol Biol Evol 4, 406-425.

Sambrook, J., Fritsch, E. F. \& Maniatis, T. (1989). Molecular Cloning: a Laboratory Manual, 2nd edn. Cold Spring Harbor, NY: Cold Spring Harbor Laboratory.

Sauer, U., Canonaco, F., Heri, S., Perrenoud, A. \& Fischer, E. (2004). The soluble and membrane-bound transhydrogenases UdhA and PntAB have divergent functions in NADPH metabolism of Escherichia coli. J Biol Chem 279, 6613-6619.
Schink, B. (1984). Fermentation of 2,3-butanediol by Pelobacter carbinolicus sp. nov. and Pelobacter propionicus sp. nov., and evidence for propionate formation from $\mathrm{C}_{2}$ compounds. Arch Microbiol 137, 34-41.

Schroder, I., Johnson, E. \& de Vries, S. (2003). Microbial ferric iron reductases. FEMS Microbiol Rev 27, 427-447.

Schut, G. J., Brehm, S. D., Datta, S. \& Adams, M. W. (2003). Wholegenome DNA microarray analysis of a hyperthermophile and an archaeon: Pyrococcus furiosus grown on carbohydrates or peptides. J Bacteriol 185, 3935-3947.

Scott, D. T., McKnight, D. M., Blunt-Harris, E. L., Kolesar, S. E. \& Lovley, D. R. (1998). Quinone moieties act as electron acceptors in the reduction of humic substances by humics-reducing microorganisms. Environ Sci Tech 32, 2984-2989.

Smith, P. K., Krohn, R. I., Hermanson, G. T., Mallia, A. K., Gartner, F. H., Provenzano, M. D., Fujimoto, E. K., Goeke, N. M., Olson, B. J. \& Klenk, D. C. (1985). Measurement of protein using bicinchoninic acid. Anal Biochem 150, 76-85.

Smyth, G. K. (2005). Limma: linear models for microarray data. In Bioinformatics and Computational Biology Solutions Using $R$ and Bioconductor, pp. 397-420. Edited by R. Gentleman, V. Carey, S. Dudoit, R. Irizarry \& W. Huber. New York: Springer.

Stutz, H. E. \& Reid, S. J. (2004). GltX from Clostridium saccharobutylicum NCP262: glutamate synthase or oxidoreductase? Biochim Biophys Acta 1676, 71-82.

Tusher, V. G., Tibshirani, R. \& Chu, G. (2001). Significance analysis of microarrays applied to the ionizing radiation response. Proc Natl Acad Sci U S A 98, 5116-5121.

Witholt, B., Boekhout, M., Brock, M., Kingma, J., Heerikhuizen, H. V. \& Leij, L. D. (1976). An efficient and reproducible procedure for the formation of spheroplasts from variously grown Escherichia coli. Anal Biochem 74, 160-170.

Woodcock, D. M., Crowther, P. J., Doherty, J., Jefferson, S., DeCruz, E., Noyer-Wiedner, M., Smith, S. S., Michael, M. Z. \& Graham, M. W. (1989). Quantitative evaluation of E. coli host strains for tolerance to cytosine methylation in plasmid and phage recombinants. Nucleic Acids Res 17, 3469-3478.

Yan, B., Methé, B. A., Lovley, D. R. \& Krushkal, J. (2004). Computational prediction of conserved operons and phylogenetic footprinting of transcription regulatory elements in the metalreducing bacterial family Geobacteraceae. J Theor Biol 230, 133-144.

Edited by: M. Tien 